\section{Interference of PCR Amplification by the Polyamines, Spermine and Spermidine}

\author{
Hannu Ahokas ${ }^{1,2}$ and \\ Maria J. Erkkilä \\ ${ }^{1}$ Plant Breeding Institute, ARC, \\ SF-31600 Jokioinen, Finland; \\ ${ }^{2}$ Department of Genetics, SF-00014 \\ University of Helsinki, \\ Helsinki, Finland
}

In a recent article describing the effects of various reaction conditions, Blanchard et al. ${ }^{(1)}$ mentioned that spermine and spermidine at concentrations between 0.5 and $3 \mathrm{~mm}$ had no effect on PCR amplification ${ }^{(2,3)}$ with their sequence-specific primers. Because we have observed with arbitrary primers and other DNA templates the concentration-dependent effects of spermine and spermidine either alone or together in PCR, we would like to report our experiences here. The present experiments were run in 1991 and may therefore carry outdated features.

The observation that barley (Hordeum vulgare) DNA samples isolated by two different methods, that of Wienand and Feix ${ }^{(4)}$ and the other of Wagner et al., ${ }^{(5)}$ yielded different results when used as PCR templates gave an impetus to the present study. We deduced that a component was carried along with DNA from the solutions used in the latter method, which keeps the nucleic acids precipitated in the early stages of the procedure with PEG in the presence of polyamines. It appeared that the polyamines, spermine and spermidine, either alone or together in the PCR mix, explained the observed patterns of amplification described below. Hence, some polyamines were supposed to be carried with the DNA over the subsequent steps of isolation. Polyamines have been used in a few assay buffers of nucleic acids affecting enzymes, but their effects were not found to be beneficial in all cases, for example, with restriction endonucleases. $^{(6,7)}$

\section{MATERIALS AND METHODS}

\section{DNA Isolation}

Seedlings of barley cv. Adorra and its near isogenic experimental lines, 86HA2-64 and 86-HA2-65, were used at the two-leaf stage. They were frozen with liquid nitrogen and ground (while frozen) with a mortar and pestle. The DNA was prepared according to the method of Wienand and Feix ${ }^{(4)}$ with modifications, that is, ending the procedure after ethanol precipitation by washing twice with $70 \%$ ethanol first containing ammonium acetate $(10 \mathrm{~mm}$, molecular biology

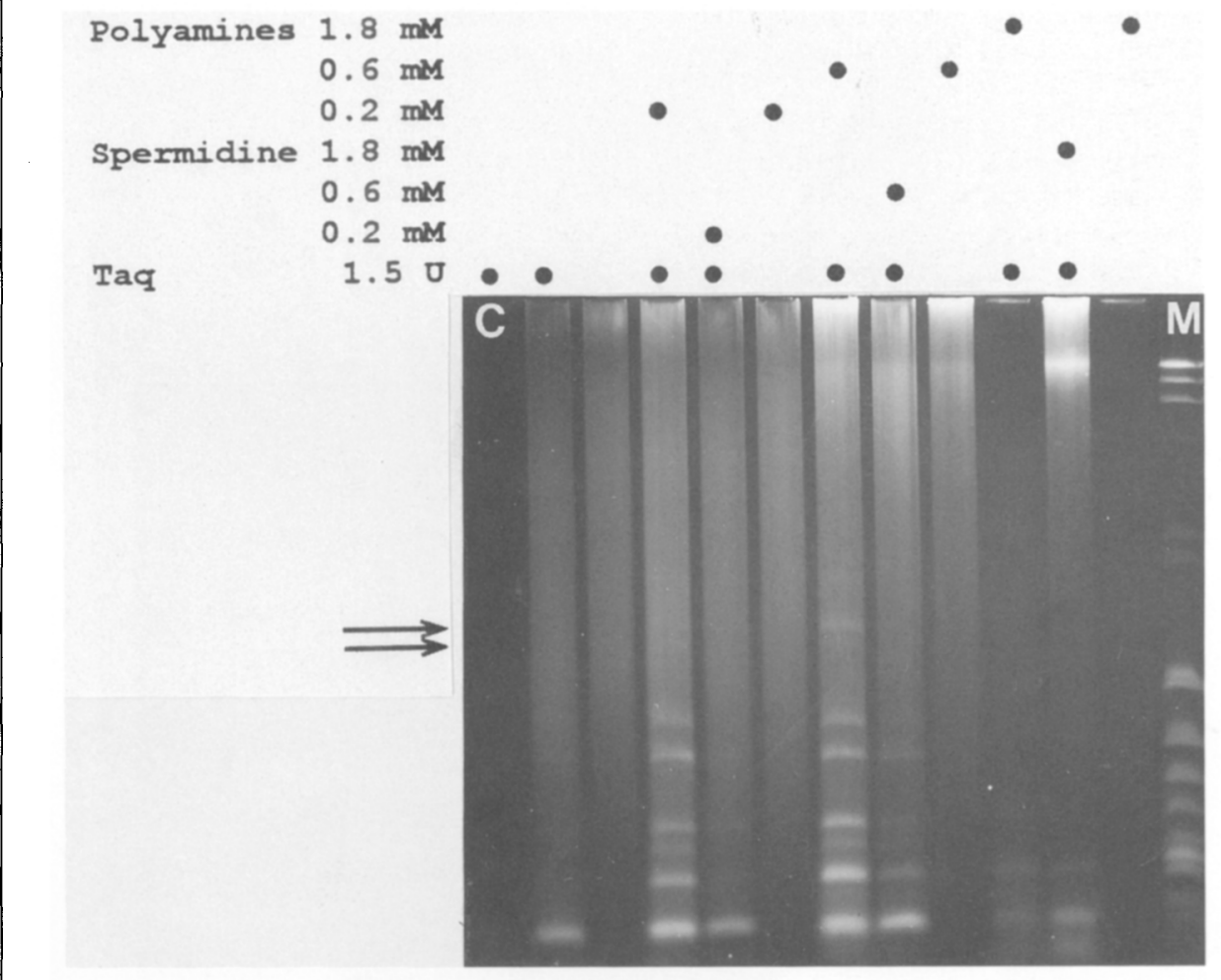

FIGURE 1 Taq amplification of barley cv. 86-HA2-64 DNA in the presence of the polyamines, spermine and spermidine at a molar ratio of $1: 2$, or spermidine alone at different concentrations. (C) Control without template DNA; (M) molecular size marker. Black dots indicate the presence of various compounds in the reaction mixtures resolved in the electrophoretic tracks below. The upper arrow indicates the 1400-bp zone; the lower arrow, the 1200-bp zone. 


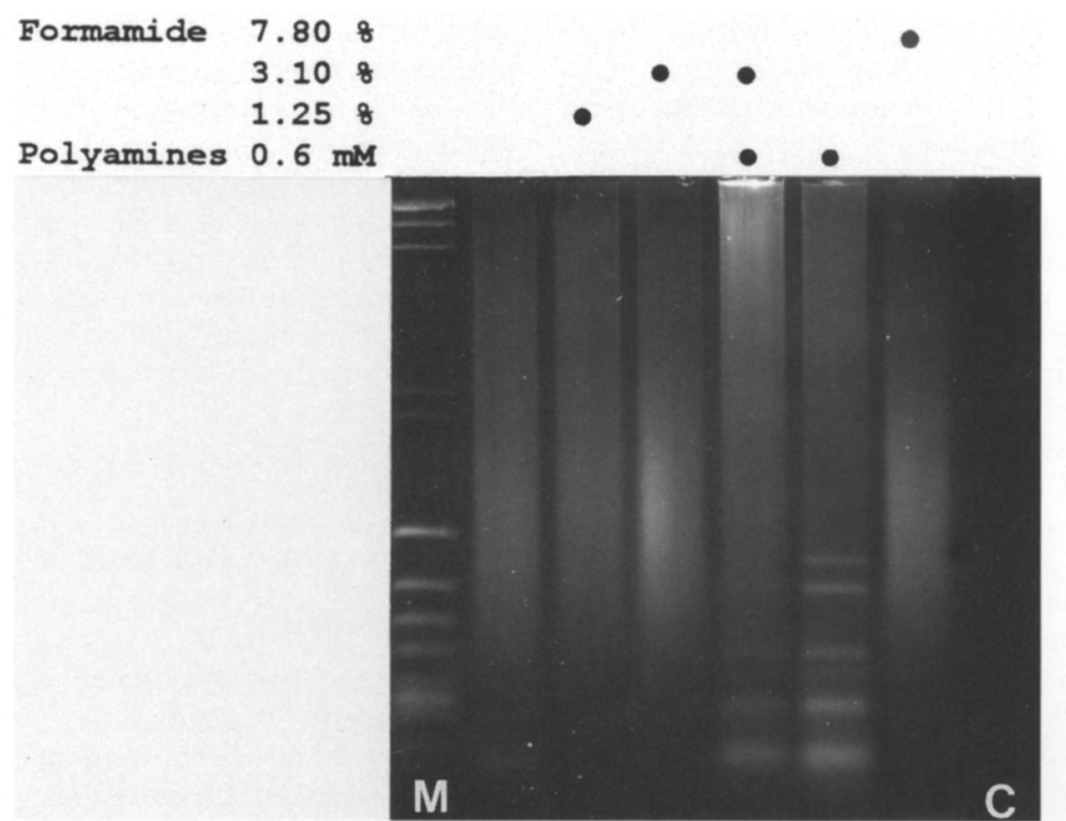

FIGURE 2 Taq amplification of barley cv. 86-HA2-64 DNA in the presence of various concentrations of formamide with or without polyamines (spermine and spermidine, molar ratio $1: 2$ ). (M) Molecular size marker; (C) control without template DNA. grade from Sigma) and then without ammonium acetate. RNA was removed with DNase-free RNase I " $A$ " (Pharmacia). High levels of RNA may be suppressive to PCR amplification. ${ }^{(8)}$ DNA was dissolved in TE buffer (10:1, pH 7.4). DNA con- centrations were determined with a DNA fluorometer (Hoefer) using calf thymus DNA as the standard. Most of the experiments were done with cv. 86-HA2-64 DNA; some were repeated with DNAs of other genotypes.

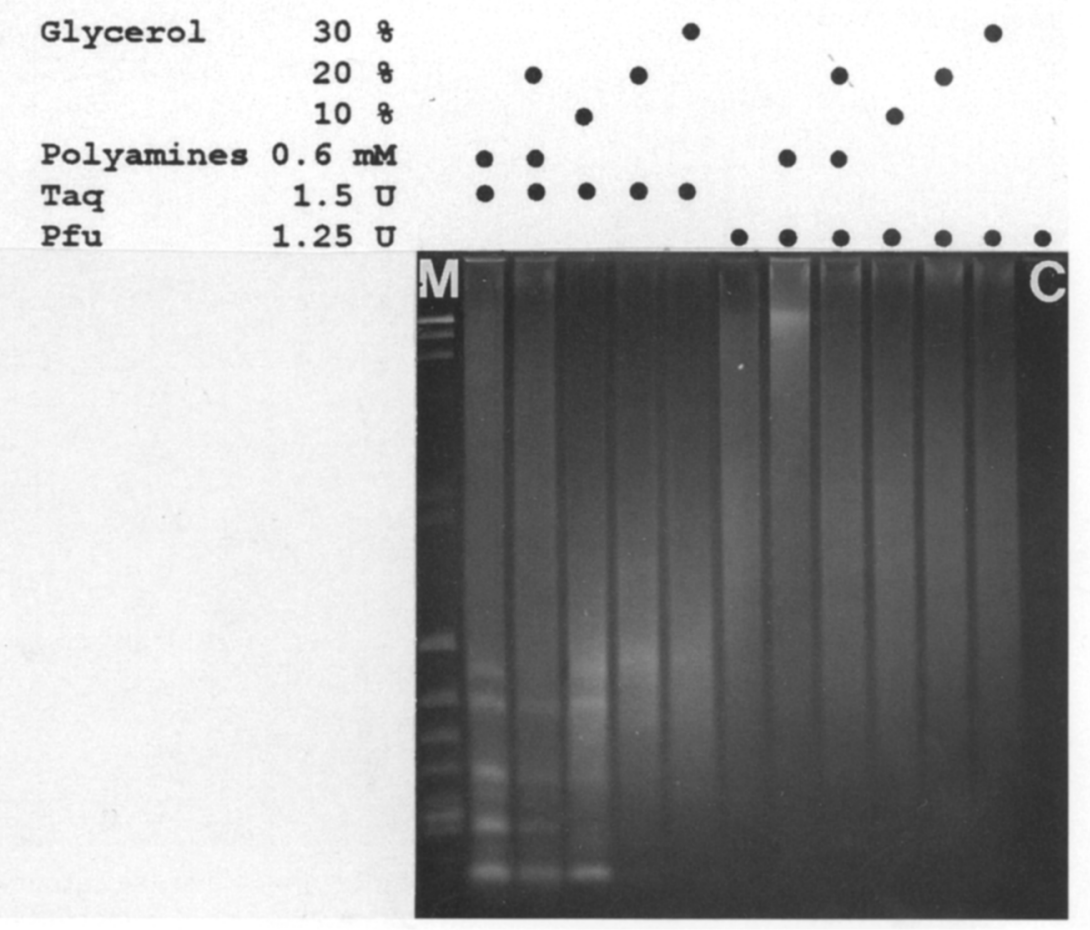

FIGURE $3 \mathrm{Taq}$ and $P f u$ amplification of barley cv. 86-HA2-64 DNA as the template with various concentrations of glycerol with or without polyamines (spermine and spermidine, molar ratio 1:2). (M) Molecular size marker; (C) Pfu control without template DNA.

\section{Primers and PCR Conditions}

The primers were prepared with an ABI DNA/RNA 392 synthesizer using SmallScale Wide-Pore T CPG columns (according to the instructions of the manufacturer) with ABI chemicals. The primers were used without purification, or they were purified further with Millipore Sep-Pak $\mathrm{C}_{18}$ columns. ${ }^{(9-12)}$ The arbitrary primer sequences were TTACCTCCACTTGCACT and CAGCCACACGAGGACCT. Each of them was applied at $\sim 1.5 \mu \mathrm{M}$ concentration. The amount of the template DNA was $\sim 0.5 \mu \mathrm{g}$ in a final volume of $50 \mu$ l covered with $40 \mu \mathrm{l}$ of mineral oil (Sigma) in $0.5-\mathrm{ml}$ tubes. Spermine tetrahydrochloride and spermidine (molecular biology grade) were from Sigma, analytical grade glycerol from Merck, and analytical grade formamide from Fluka. Before use, formamide was deionized with Bio-Rad AG508-X8 beads. ${ }^{(9)}$ The thermotolerant DNA polymerases used or tested were as follows: AmpliTaq from Perkin-Elmer Cetus (1.5 unit per reaction), Taq from Promega (1.5 unit per reaction), Vent from New England Biolabs (1 unit per reaction), and $P f u$ from Stratagene (1.25 unit per reaction). The $10 \times$ buffer supplied by each manufacturer was used in the master mix containing the dNTPs (Promega or Perkin-Elmer Cetus), each at a concentration of $300 \mu \mathrm{M}$. Spermine and spermidine, in the molar ratio of $1: 2$, were added from stock solutions to make a final pooled concentration of $0.05,0.2$, 0.6 , or $1.8 \mathrm{~mm}$. The PCR (Techne PHC-2) running parameters were 10 cycles of $97^{\circ} \mathrm{C}, 55^{\circ} \mathrm{C}$, and $72^{\circ} \mathrm{C}$ (each for $1 \mathrm{~min}$ ), and 30 cycles of $94^{\circ} \mathrm{C}, 55^{\circ} \mathrm{C}$ (both for 1 $\min$ ), and $72^{\circ} \mathrm{C}$ (for $2 \mathrm{~min}$ ). The run was terminated at $72^{\circ} \mathrm{C}$ for $4 \mathrm{~min}$. The amplified DNA was resolved with horizontal electrophoresis in $0.8 \%$ SeaPlaque agarose (FMC) gels using $1 \times$ TBE buffer. Samples of $30 \mu \mathrm{l}$ of the PCR products were mixed with $15 \mu \mathrm{l}$ of sample buffer ${ }^{(13)}$ containing ethidium bromide. ${ }^{(14)}$ The gels were poststained with ethidium bromide if necessary. The molecular size marker was a $\lambda$ DNA HindIII/ ФX-174 RF DNA HincII digest (Pharmacia), with the following visible zones after electrophoresis (from top to bottom, see Figs. 1-4): 23130, 9416, 6557, 4361, 2322, 2027, 1057, 770, 609, 495, $392,345,341,335,297$, and 291 bp. The buffer $\mathrm{pH}$ was measured using a Knick 761 Calimatic pH meter with an Ingold 


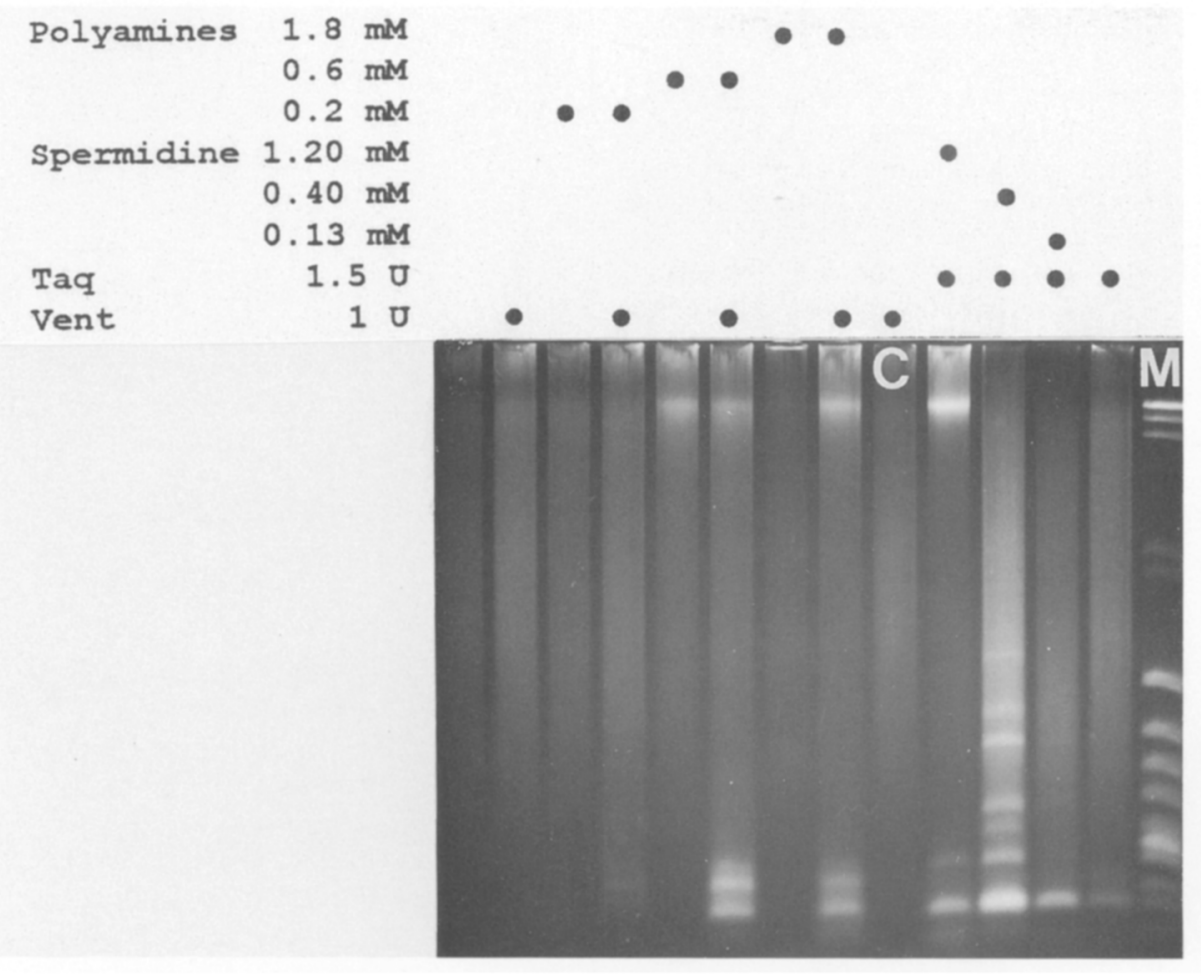

FIGURE 4 Vent amplification of barley cv. 86-HA2-64 DNA in the presence of various concentrations of polyamines (spermine and spermidine, molar ratio $1: 2$ ). Taq amplification with spermidine. (C) Vent control without template DNA; (M) molecular size marker.

combined electrode and a temperature sensor.

\section{RESULTS AND DISCUSSION}

If not specified otherwise, the results describe amplifications with AmpliTaq polymerase. The optimum concentration of the pooled polyamines was found to be $0.6 \mathrm{~mm}$ (Fig. 1). Without added polyamines, PCR normally resulted in zero or one zone, or up to six zones of short fragments. A polyamine concentration of $0.2 \mathrm{~mm}$ usually resulted in 6 fragments, and that of $0.6 \mathrm{~mm}$ in up to 10 fragments. The largest fragments were $\sim 1800$ bp (weakly visible), followed by one of $1400 \mathrm{bp}$, and one of $1200 \mathrm{bp}$. These large fragments were observed in most runs at the optimum concentration of the polyamines. When tested separately, spermidine was more efficient than spermine (result not shown) in promoting the amplification. The optimum concentrations of spermine and spermidine ranged from $\sim 0.4$ $\mathrm{m}$ to $0.6 \mathrm{~mm}$. However, the maximal promotion was obtained with the mixture (Fig. 1), the ratio of which was obtained by the referred method. ${ }^{(5)}$ The highest polyamine concentrations were sometimes observed to cause precipitation in the samples.

Formamide was shown to promote the specificity of amplification. ${ }^{(15)}$ In the present material, with formamide alone at the concentrations of $1.25 \%, 3.1 \%$, or $7.8 \%$, no amplification was observed. Formamide $(3.1 \%)$ in combination with polyamines $(0.6 \mathrm{~mm})$ partially inhibited the promoting effect of polyamines (Fig. 2). A barley GC-rich sequence was reported to be successfully amplified in the presence of glycerol. ${ }^{(16)}$ In the present material, glycerol was tested at final concentrations of $10 \%, 20 \%$, and $30 \%$, and the $20 \%$ concentration was also amplified in a reaction mix containing $0.6 \mathrm{~mm}$ polyamines. Glycerol partly inhibited the effect of polyamines but, curiously, at $10 \%$ concentration, slighty promoted amplification of fragments of similar sizes as did polyamines at a concentration of $0.6 \mathrm{~mm}$ (Fig. 3).

Of the different polymerases suitable for PCR, $P f u$ did not produce any visible amplification either with or without polyamines or glycerol (Fig. 3). Vent polymerase amplification was promoted with the polyamine mix at an optimum concentration of $0.6 \mathrm{~mm}$. However, Vent amplified the three or four shortest fragments common to those of Taq, but their amplification intensities were different (Fig. 4).

The effect of polyamines cannot simply be explained as a $\mathrm{pH}$ effect because no coherent rise of $\mathrm{pH}$ was seen in the Taq buffer at these concentrations. At concentrations of $0,0.2,0.6$, and $1.8 \mathrm{~mm}$ of the polyamines, the $\mathrm{pH}$ readings of the $1 \times$ Taq buffer varied from 8.32 to 8.45 at $19.4^{\circ} \mathrm{C}$, and from 7.27 to 7.58 at $72^{\circ} \mathrm{C}$. Raising the assay buffer $\mathrm{pH}$ has been shown to promote amplification but to decrease the stringency of the PCR amplification. ${ }^{(1)}$

The radiolabeled fragments of 1200 and $1400 \mathrm{bp}$ hybridize to restricted barley DNA. The present observations imply also that the DNA isolation method may be a source of variation in PCR amplification. A number of other variables, too, have been shown to affect the results. ${ }^{(1,8,17-19)}$ It is possible that the binding of polyamines on DNA affects the apparent availability of the DNA template. The ratio of primer to template is one of the efficiency determinants in PCR. ${ }^{(19)}$ A preliminary study using another arbitrary primer pair and barley DNA as the template supports the observed promotion of PCR amplification by polyamines (results not shown). The use of a DNA isolation method with polyamines in the solution involves the risk of carryover of the polyamines with the DNA at a concentration affecting their template properties in PCR.

\section{ACKNOWLEDGMENTS}

This work was supported by a grant from the Ministry of Agriculture and Forestry of Finland.

\section{REFERENCES}

1. Blanchard, M.M., P. Taillon-Miller, P. Nowotny, and V. Nowotny. 1993. PCR buffer optimization with uniform temperature regimen to facilitate automation. $P C R$ Methods Applic. 2: 234-240.

2. Saiki, R.K., S. Scharf, F. Faloona, K.B. Mullis, G.T. Horn, H.A. Erlich, and N. Arnheim. 1985. Enzymatic amplification of $\beta$-globin genomic sequences and restriction site analysis for diagnosis of sickle cell anemia. Science 230: 1350-1354.

3. Mullis, K., F. Faloona, S. Scharf, R. Saiki, G. Horn, and H. Erlich. 1986. Specific en- 


\section{Technical TipsIIIII}

zymatic amplification of DNA in vitro: The polymerase chain reaction. Cold Spring Harbor Symp. Quant. Biol. 51: 263273.

4. Wienand, U. and G. Feix. 1980. Zein specific restriction enzyme fragments of maize DNA. FEBS Lett. 116: 14-16.

5. Wagner, D.B., G.R. Furnier, M.A. SaghaiMaroof, S.M. Williams, B.P. Dancik, and R.W. Allard. 1987. Chloroplast DNA polymorphisms in lodgepole and jack pines and their hybrids. Proc. Natl. Acad. Sci. 84: 2097-2100.

6. Pingoud, A., C. Urbanke, J. Alves, H.-J. Ehbrecht, M. Zabeau, and C. Gualerzi. 1984. Effect of polyamines and basic proteins on cleavage of DNA by restriction endonucleases. Biochemistry 23: 5697-5703.

7. Kuosmanen, M. and H. Pösö. 1985. Inhibition of the activity of restriction endonucleases by spermidine and spermine. FEBS Lett. 179: 17-20.

8. Pikaart, M.J. and B. Villeponteau. 1993. Suppression of PCR amplification by high levels of RNA. BioTechniques 14: 24-25.

9. Sambrook, J., E.F. Fritsch, and T. Maniatis. 1989. Molecular cloning: A laboratory manual; 2nd ed. Cold Spring Harbor Laboratory Press, Cold Spring Harbor, New York.

10. Lo, K.-M., S.S. Jones, N.R. Hackett, and H.G. Khorana. 1984. Specific amino acid substitutions in bacterioopsin: Replacement of a restriction fragment in the structural gene by synthetic DNA fragments containing altered codons. Proc. Natl. Acad. Sci. 81: 2285-2289.

11. Sanchez-Pescador, R. and M.S. Urdea. 1984. Use of unpurified synthetic deoxynucleotide primers for rapid dideoxynucleotide chain termination sequencing. DNA 3: 339-343.

12. Zoller, M.J. and M. Smith. 1984. Oligonucleotide-directed mutagenesis: A simple method using two oligonucleotide primers and a single-stranded DNA template. DNA 3: 479-488.

13. Anonymous. 1985 . Typical procedure for the determination of the volume activity of restriction endonucleases. "Biochemicals for Molecular Biology," p. 87. Boehringer, Mannheim.

14. Angermüller, S.A. and L.A. SayavedraSoto. 1990. Rapid visualization of genomic DNA and total RNA in agarose gels. BioTechniques 8: 36, 38.

15. Sarkar, G., S. Kapelner, and S.S. Sommer. 1990. Formamide can dramatically improve the specificity of PCR. Nucleic Acids Res. 18: 7465.

16. Henry, R.J. and K. Oono. 1991. Amplification of a GC-rich sequence from barley by a two-step polymerase chain reaction in glycerol. Plant Mol. Biol. Rep. 9: 139-144.

17. Chou, Q., M. Russell, D.E. Birch, J. Raymond, and W. Bloch. 1992. Prevention of pre-PCR mis-priming and primer dimerization improves low-copy-number am- plifications. Nucleic Acids Res. 20: $1717-$ 1723.

18. Ellsworth, D.L., K.D. Rittenhouse, and R.L. Honeycutt. 1993. Artifactual variation in randomly amplified polymorphic DNA banding patterns. BioTechniques 14: 214, 216, 217.

19. Muralidharan, K. and E.K. Wakeland. 1993. Concentration of primer and template qualitatively affects products in random-amplified polymorphic DNA PCR. BioTechniques 14: 362, 364.

Received April 23, 1993; accepted in revised form June 22, 1993. 


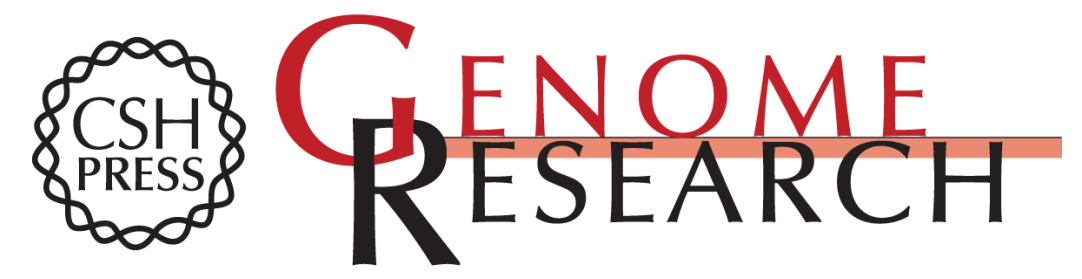

\section{Interference of PCR amplification by the polyamines, spermine and spermidine.}

$\mathrm{H}$ Ahokas and M J Erkkilä

Genome Res. 1993 3: 65-68

References This article cites 17 articles, 4 of which can be accessed free at: http://genome.cshlp.org/content/3/1/65.full.html\#ref-list-1

\section{License}

Email Alerting

Receive free email alerts when new articles cite this article - sign up in the box at the Service top right corner of the article or click here.

\section{Affordable, Accurate Sequencing.}

To subscribe to Genome Research go to:

https://genome.cshlp.org/subscriptions 